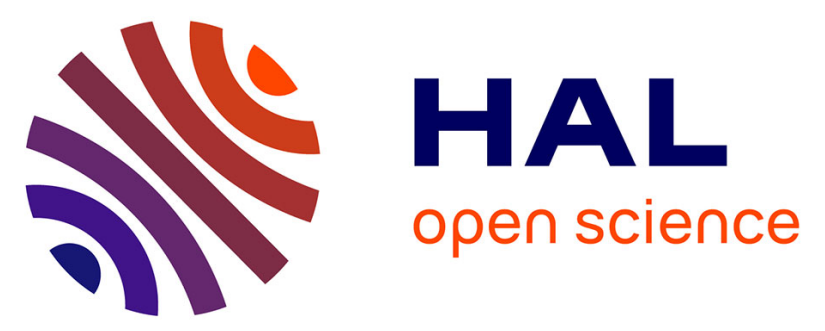

\title{
Postoperative Peritonitis After Digestive Tract Surgery: Surgical Management and Risk Factors for Morbidity and Mortality, a Cohort of 191 Patients
}

Thierry Bensignor, Jeremie Lefevre, Ben Creavin, Najim Chafai, Thomas Lescot, Thévy Hor, Clotilde Debove, François Paye, Pierre Balladur, Emmanuel Tiret, et al.

\section{To cite this version:}

Thierry Bensignor, Jeremie Lefevre, Ben Creavin, Najim Chafai, Thomas Lescot, et al.. Postoperative Peritonitis After Digestive Tract Surgery: Surgical Management and Risk Factors for Morbidity and Mortality, a Cohort of 191 Patients. World Journal of Surgery, 2018, 42 (11), pp.3589 - 3598. 10.1007/s00268-018-4687-6 . hal-01912296

\section{HAL Id: hal-01912296 \\ https://hal.sorbonne-universite.fr/hal-01912296}

Submitted on 5 Nov 2018

HAL is a multi-disciplinary open access archive for the deposit and dissemination of scientific research documents, whether they are published or not. The documents may come from teaching and research institutions in France or abroad, or from public or private research centers.
L'archive ouverte pluridisciplinaire HAL, est destinée au dépôt et à la diffusion de documents scientifiques de niveau recherche, publiés ou non, émanant des établissements d'enseignement et de recherche français ou étrangers, des laboratoires publics ou privés. 


\section{POSTOPERATIVE PERITONITIS AFTER DIGESTIVE TRACT SURGERY: SURGICAL MANAGEMENT AND RISK FACTORS OF MORBIDITY and MORTALITY, A COHORT OF 191 PATIENTS.}

Thierry Bensignor (MD) ${ }^{1}$, Jérémie H. Lefevre, $(\mathrm{MD}, \mathrm{PhD})^{1}{ }^{1}$, Ben Creavin (MD) ${ }^{3}$, Najim Chafai (MD) ${ }^{1}$, Thomas Lescot (MD, PhD) ${ }^{2}$, Thévy Hor (MD) ${ }^{1}$, Clotilde Debove (MD) ${ }^{1}$, François Paye (MD, PhD) ${ }^{1}$, Pierre Balladur (MD) ${ }^{1}$, Emmanuel Tiret (MD) ${ }^{1}$, Yann Parc (MD, PhD) ${ }^{1}$

${ }^{1}$ Departement of General and Digestive Surgery, Hôpital Saint-Antoine, Assistance Publique Hôpitaux de Paris, Université Pierre et Marie Curie, 75012, Paris

${ }^{2}$ Departement of Surgical Intensive Care, Hôpital Saint-Antoine, Assistance Publique Hôpitaux de Paris, Université Pierre et Marie Curie, 75012, Paris

3 Department of Colorectal Surgery, St Vincent's University Hospital, Elm Park, Dublin 4, Ireland.

\section{Correspondence and reprint requests:}

Pr Jérémie Lefevre, Department of Digestive Surgery, Hôpital Saint-Antoine, Assistance Publique Hôpitaux de Paris, Université Pierre et Marie Curie, Paris VI, 184 rue du Faubourg Saint-Antoine, 75012, Paris, France

Tel: 00331492825 47, Fax : 0033149282548

e-mail: jeremie.lefevre@aphp.fr

Short title: postoperative peritonitis.

No Disclosure to report. No financial support.

Keywords: critical care; gastrointestinal; outcomes.

Author contribution:

- Data collection: TB, NC, TL, TH, CD

- Intrepretation of data: TB, JHL, FP, PB, ET, YP

- Data analysis: TN, JHL, BC.

- Manuscript drafting: TB, JHL, BC, YP

- Manuscript revision: NC, TL, TH, CD, FP, PB, ET

- Final approval: all authors

- Accountable for all aspect of the work: all authors. 


\begin{abstract}
Background: Post-operative peritonitis (POP) following gastrointestinal surgery is associated with significant morbidity and mortality, with no clear management option proposed. The aim of this study was to report our surgical management of POP and identify pre- and perioperative risk factors of morbidity and mortality.
\end{abstract}

Methods: All patients with POP undergoing relaparotomy in our department between January 2004 and December 2013 were included. Pre and perioperative data was analyzed to identify predictors of morbidity and mortality.

Results: A total of 191 patients required relaparotomy for POP, of which $16.8 \%$ required >1 reinterventions. The commonest cause of POP was anastomotic leakage (66.5\%) followed by perforation (20.9\%). POP was mostly treated by anastomotic take-down (51.8\%), suture with derivative stoma $(11.5 \%)$, enteral resection and stoma (12\%), drainage of the leak (8.9\%), stoma on perforation (8.4\%), duodenal intubation (7.3\%) or intubation of the leak (3.1\%). The overall mortality rate was $14 \%$, of which $40 \%$ died within the first 48 hours. Major complications (Dindo-Clavien >2) were seen in $47 \%$ of the cohort. Stoma formation occurred in $81.6 \%$ of patients following relaparotomy. Independent risk factors of mortality were: ASA $>2(\mathrm{OR}=2.75$, 95\% CI=1.07-7.62, $\mathrm{p}=0.037)$, Multi-Organ Failure $(\mathrm{MOF}) \quad(\mathrm{OR}=5.22,95 \% \mathrm{CI}=2.11-13.5, \mathrm{p}=0.0037)$, perioperative transfusion $(\mathrm{OR}=2.7,95 \% \mathrm{CI}=1.05-7.47, \mathrm{p}=0.04)$ and upper $\mathrm{GI}$ origin $(\mathrm{OR}=3.55,95 \% \mathrm{CI}=1.32$ 9.56, $\mathrm{p}=0.013)$. Independent risk factors of morbidity were: $\mathrm{MOF}(\mathrm{OR}=2.74,95 \% \mathrm{CI}=1.26-6.19, \mathrm{p}=0.013)$, upper GI origin $(\mathrm{OR}=3.74,95 \% \mathrm{CI}=1.59-9.44, \mathrm{p}=0.0034)$ and delayed extubation $(\mathrm{OR}=0.27,95 \% \mathrm{CI}=0.14$ $0.55, \mathrm{p}=0.0027)$.

Conclusion: Mortality following POP remains a significant issue, however, is decreasing due to effective and aggressive surgical intervention. Predictors of poor outcomes will help tailor management options. 


\section{INTRODUCTION}

Postoperative peritonitis (POP) is the most feared complication after gastrointestinal surgery, with incidence ranging from $0.7-3.5 \%^{1,2}$. While POP remains the commonest cause of death in gastrointestinal surgery, mortality rates have decreased from $60 \%$ to $20 \%$ over the past few decades ${ }^{1,3,4}$.

The causes of POP are multifactorial, however, are commonly associated with anastomotic leaks and perforations ${ }^{5,6}$. Anastomotic leaks are accompanied with increased morbidity, mortality, length of stay and hospital costs ${ }^{7}$. Multiple studies have identified risk factors associated with anastomotic leaks, however, few have reported on the surgical management of POP ${ }^{1,8}$. Yeast or enterococcus infections, unsuitable antibiotic therapy and surgical reintervention for sepsis control are associated risk factors for mortality in the post-operative setting ${ }^{3,5,9,10}$. Furthermore, limited studies assessing perioperative mortality risk factors have identified age, hyper/hypothermia and mechanical ventilation as significant factors ${ }^{3,5,9,10}$. Current evidence is lacking on the prognosis of patients following POP. Stratification of patients according to severity is needed to guide appropriate management and prognosis of patients.

The aim of this study was to report the surgical approach of POP and to identify pre- or perioperative risk factors associated with severe morbidity and mortality. 


\section{PATIENTS \& METHODS}

\section{Patients}

A retrospective review of all patients undergoing re-laparotomy for POP following gastrointestinal surgery was performed from January 2004 to December 2013. POP after bariatric, hepatic or pancreatic surgery was excluded to obtain a homogenous population.

Patient characteristics, including past medical history and American Society of Anesthesiology (ASA) score, details of initial surgery and clinical presentation at time of relaparotomy were retrospectively collected from the patient's charts. APACHE II score was calculated based of the data prior to relaparotomy.

Operative findings were recorded and the Manheim index was calculated using the reintervention operative

report ${ }^{11}$. Data on the origin of peritonitis, surgical management, types of drainage and wound closure was collected.

For postoperative outcomes, death, surgical and medical complications, catecholamines infusion, delayed extubation and enteral nutrition data was collected. Complications were classified according to the ClavienDindo Classification ${ }^{12}$. Initial relaparotomy for POP and immediate postoperative intensive care admissions were not considered as complications.

\section{Surgical approach}

During relaparotomy, the entire peritoneal cavity and all previous suture sites were explored for evidence of a septic source. Peritoneal fluid was systematically sampled for microbiology analysis. A lavage was performed with warm saline to dilute the bacterial inoculum. Peritoneal drainage was performed based on surgeon preference and operative findings. Generalized peritonitis required multiple drains including at the site of leakage and/or the hypochondriums and Douglas pouch. Localized peritonitis was managed by local drainage of the sepsis. Passive drainage with Penrose drain was the commonest drain used.

A decision on surgical management was based on the findings at relaparotomy.

Intestinal perforation was treated according to the site: (1) for duodenal perforation, an intubation of the defect was performed with a Helisonde drain ${ }^{\circledR}$ associated with two closed suction drains and a Penrose drain 
placed behind and in front of the helicoidal drain as previously described ${ }^{13-15}$; (2) for small bowel perforation, a stoma was created at the perforation site and; (3) for colonic perforation, a stoma was performed at the perforation site if possible or a colonic resection was performed with the formation of a stoma.

Anastomotic leakage was treated by drainage or in most cases by a take-down of the anastomosis. The decision was made in accordance with the intra-operative findings and the general condition of the patient. Drain management was only performed for defects $<1 \mathrm{~cm}$ with minimal inflammation of the peritoneum. Three drainage approaches were performed: (1) drain in contact with the defect; (2) Intubation of the defect with a Helisonde drain ${ }^{\circledR}$; (3) drain in contact with the defect with diverting stoma formation in cases of pelvic anastomotic leaks following intra-operative colonic lavage.

In case of the take down of an oesophagojejunal anastomosis, the esophageal stump was intubated with a Helisonde drain ${ }^{\circledR}$ to keep the esophagus in the abdomen and a stoma was made with the Roux en Y jejunum. In the case of a colorectal or coloanal anastomotic take down, a Hartmann procedure was performed and a pelvic drain with a Mikulicz was placed as previously described ${ }^{15}$.

\section{Postoperative care}

Following relaparotomy, patients were cared for in an ICU or ward based setting depending on anesthesiologist and surgeon choice.

Broad-spectrum antibiotics were systematically used postoperatively and were tailored based on bacteria cultured from swabs taken at the time of relaparotomy. Empirical antifungal treatment was added in case of a Dupont's score of 3 or more and systematically adapted to the yeast species ${ }^{16}$.

Parenteral nutrition support was started to provide $25 \mathrm{kCal} / \mathrm{kg}$ and was switched to enteral nutrition as soon as possible. Bile or chyme reinfusion was performed when patient had a proximal jejunostomy ${ }^{17}$.

Drain removal was dependent on output measurements. Mikulicz packing drainage and Helisonde drain ${ }^{\circledR}$ were managed according to the department practice as previously described ${ }^{14}$. Mikulicz packing drainage was removed mesh by mesh after POD 9. The bag itself was removed at POD 14. Helisonde drain ${ }^{\circledR}$ was used to irrigate $3 \mathrm{~L}$ of saline solution to dilute secretions. Closed drains were removed after POD 5. After 
their removal, the Helisonde drain ${ }^{\circledR}$ was removed by turning it two counter-clockwise turns each day and was eventually replaced with a $12 \mathrm{~F}$ silicone drain.

\section{Statistical analysis}

Morbidity and mortality risk factors were evaluated by including 15 and 20 variables in the univariate analysis respectively: sex, age, American Society of Anesthesiologists (ASA), malnutrition, neoplasia, origin of the peritonitis (upper or lower gastrointestinal tract (GI)), transferred patient, multiorgan failure (MOF) at relaparotomy, presence of shock at relaparotomy, peritonitis $>24$ hours, transfusion during relaparotomy, Mannheim Score, APACHE II score, immediate postoperative extubation, delayed enteral nutrition, plus for mortality: renal failure, respiratory failure, presence of one or more septic source, generalized or local peritonitis and delay of relaparotomy. Univariate analysis was performed using Chi square, Fisher's exact test or a Student's t test when appropriate. The Mannheim Peritonitis Index and the APACHE II score were not included in the multivariate analysis, as we preferred to evaluate relevant variables of each scoring systems. Multivariate analysis was performed using a multivariate regression. All variables with a $\mathrm{p}$ value $<0.2$ were included. A $\mathrm{p}$ value $<0.05$ was considered to be statistically significant. Statistical analysis was carried out using the SPSS 21.0 software (IBM Corp. Released 2012. IBM SPSS Statistics for Windows, Version 21.0. Armonk, NY: IBM Corp.). 


\section{RESULTS}

\section{Patients' characteristics}

A total of 191 patients underwent relaparotomy for POP during the study interval. Patient and surgical indication are summarized in Table 1 and 2 respectively. Thirty-six patients (18.8\%) had upper GI surgery while $155(81.2 \%)$ had lower GI surgery. Ninety-two patients had a history of previous abdominal surgery including 67 procedures with gastrointestinal resections or peritonitis. A further 8 patients had a previous postoperative peritonitis.

Forty-one patients $(21 \%)$ initially had emergency surgery, nine for peritonitis, including 3 perforated diverticulitis, 4 perforated Crohn disease, 1 perforated small bowel obstruction and 1 perforation during the endoscopic procedure. Twenty-three had an anastomosis performed during the emergency procedure including 3 patients with peritonitis, one Crohn's disease (ileocolic anastomosis), one perforated diverticulitis (colorectal anastomosis with derivative stoma) and the endoscopic perforation (colocolic anastomosis).

The majority of patients $(n=154 ; 80.6 \%)$ had had an anastomosis performed during the initial procedure.

\section{Clinical presentation}

Table 3 shows the clinical presentation at diagnosis of POP. Most frequent signs were abdominal pain (82\%), tachycardia (61\%) and fever (49\%).

A CT-scan was performed in $65 \%$ of patients. The remaining patients had either generalized peritonitis, abnormal leakage through a drain or abdominal scar with signs of sepsis or multi organ failure that could not delay intervention.

\section{Transferred patients}

Among the 191 patients, 63 (33\%) were transferred from another hospital to our centre for POP management. The mean delay to transfer was 16 days $(0-57)$ after initial surgery. Most patients were transferred for a leak through the scar or drain associated with septic signs, septic shock $(\mathrm{n}=25 ; 38.7 \%)$ or 
multi organ failure $(n=13 ; 20.6 \%)$. The majority of patients had undergone at least one relaparotomy prior to transfer $(\mathrm{n}=37.58 .6 \%)$.

\section{Relaparotomy}

Details of all relaparotomies are given in table 4. Relaparotomies occurred after a mean delay of 9 (1-195) days following first procedure. The majority of patients $(n=153 ; 80.1 \%)$ had only one cause of peritonitis.

In the case of anastomotic leaks $(n=127)$, the main management was take down of the anastomosis $(99 / 127$; $78 \%$ ) with formation of a stoma. Intubation of the leak was only performed in the case of upper GI defects $(6 / 127 ; 4.7 \%)$ whereas suture closure of the defect with protective stoma formation was performed for coloanal or low colorectal anastomosis $(18 / 127 ; 14.2 \%)$. Three patients $(1.6 \%)$ had simple drainage close to the leakage and only one patient had a redo anastomosis.

Duodenal defects were mostly treated by intubation of the defects $(14 / 16 ; 87.5 \%)$. Only two patients had a simple drainage. Thirty-eight patients had a gastrointestinal perforation. All colonic and enteral perforations were used in the formation of a stoma. Eventually, 156 patients (81.7\%) had one or more stomas after relaparotomy.

\section{Postoperative course}

Postoperative course and complications are summarized in Table 5. Overall mortality was $14.1 \%(\mathrm{n}=27)$. The majority of deaths occurred between POD 0-10 (n=16;59\%) including 11 deaths $(41 \%)$ in the first 48 hours from MOF due to POP $(n=10)$ and one for a myocardial infarction. Three deaths $(11 \%)$ occurred between POD 10-20 with 9 deaths (33\%) after POD 20.

Immediate extubation following relaparotomy was performed in 82 patients $(42.9 \%)$. Eighty-nine patients (46.6\%) had severe postoperative complications Clavien-Dindo $\geq 3$. Only 3 patients had a scheduled second look operation. A total of 39 patients had a non-surgical procedure including 19 (10\%) radiological drainages. 


\section{Risk factors analysis}

Morbidity and mortality risk factors are summarized in Table $6 \& 7$. Four risk factors were independently associated with mortality on multivariate analysis: ASA score $\geq 3(\mathrm{OR}=2.75$; IC95 [1.07 - 7.62]; $\mathrm{p}=0.037)$, upper GI origin $(\mathrm{OR}=3.55$; IC95 [1.32 - 9.56]; $\mathrm{p}=0.013)$, MOF at relaparotomy $(\mathrm{OR}=5.22$; IC95 [2.1113.55]; $\mathrm{p}=0.0037$ ) and perioperative transfusion ( $\mathrm{OR}=2.70 ; \mathrm{IC} 95$ [1.05 - 7.47]; $\mathrm{p}=0.040$ ).

The prognostic score of mortality, ranging from 0 to 4 points (based on adding each risk factor together) was $0 \%(0 / 54), 8.3 \%(4 / 48), 16.9 \%(10 / 59), 40 \%(10 / 25)$ and $60 \%(3 / 5)$.

Three risk factors were significantly associated with morbidity on multivariate analysis: upper GI origin $(\mathrm{OR}=3.74$; IC95 [1.59 - 9.44]; $\mathrm{p}=0.0034)$, MOF at relaparotomy (OR=2.74; IC95 [1.26- 6.19]; $\mathrm{p}=0.013)$ and delayed postoperative extubation $(\mathrm{OR}=0.27$; IC95 [0.14 -0.55$] ; \mathrm{p}=0.0027)$. 


\section{DISCUSSION}

The present study included a large cohort of patients between 2004 and 2013 with secondary peritonitis following gastrointestinal surgery. This study is one of the largest to report on all aspects of POP after digestive tract surgery in a homogenous patient cohort, something that is lacking in the current literature.

We excluded patients who underwent hepatic or pancreatic surgery as prognosis and surgical interventions are different compared to gastrointestinal surgery. Likewise, bariatric surgery was also excluded as there are clear management recommendations available ${ }^{18,19}$.

Furthermore, this study is, to our knowledge, the only study to focus on pre and perioperative risk factors of morbidity and mortality, helping to aid decision-making and prognosis for surgeons.

Morbidity and mortality associated with POP remains a significant issue, however has seen a significant reduction in recent years due to aggressive and effective management ${ }^{1,3,4}$. The present study found mortality and morbidity rates of $14.1 \%$ and $46.6 \%$ respectively. Furthermore, a predicted mortality rate of $16.5 \%$ is seen in patients with a mean APACHE II score of 13 , similar to previous reports ${ }^{20}$.

Due to the retrospective nature of the study, only severe complications were reported. We excluded the index relaparotomy and admission into ICU as severe complications in order to demonstrate the true impact surgical intervention of POP has on outcomes.

The present study identified factors of the Mannheim score, upper GI and MOF as significant risk factors of mortality and severe morbidity. In the Mannheim Peritonitis Index, MOF was the most significant risk factor of mortality. Furthermore, ASA $\geq 3$ was a risk factor of mortality and is more representative of prognosis than age of the patient.

A recent study by Launey et al. found that the initial postoperative severity parameters were an independent mortality risk factor in POP ${ }^{21}$. We did not include scoring systems such as APACHE II or the Mannheim peritonitis index in the multivariate analysis because it would have prevented other variables to emerge. This allowed us to prove that MOF and origin of the peritonitis are more relevant.

The most interesting and original finding in the present study is that peri operative transfusion is associated with increased postoperative mortality by a factor of 2.7. Transfusions have been shown to be associated 
with adverse postoperative morbidity such as anastomotic leaks ${ }^{22}$ and mortality ${ }^{23-25}$. Worse survival outcomes have also been reported, especially in oncological resections ${ }^{26}$. This has been attributed to the immunosuppressive effects of blood transfusion ${ }^{27,28}$. The need for blood transfusion must therefore be weighed against its possible adverse effects. However, the need for a transfusion can represent the severity of the patient condition, especially in case of severe sepsis developing Disseminated Intravascular Coagulation (DIC) ${ }^{29}$.

Interestingly delayed extubation was also a risk factor of morbidity. Indeed, in our cohort, among the 82 patients with immediate extubation only 2 patients had pneumonia (2.4\%) vs. 24 among the 109 patients with delayed extubation (22\%). Likewise 3 patients from the immediate extubation group developed ARDS (3.7\%) versus $10(9.2 \%)$ in the delayed group. Mechanical ventilation is known to be a risk factor of pneumonia ${ }^{30}$. Early extubation and intensive chest physio are important in the post-operative setting to prevent respiratory complications after POP ${ }^{31,32}$.

Post-operative mortality was encountered early in the present study, with $40 \%$ of deaths occurring in the first $48 \mathrm{hrs}$. Controlling the initial sepsis and its subsequent consequences are the main goal in patient care ${ }^{3 \text {, }}$ 10. The current study observed a lower rate of reinterventions $(16.7 \%)$ after the first relaparotomy due to aggressive surgical management and higher rate of anastomotic take down with stoma formation a persistent septic source. Five patients among those treated by drainage methods required a further laparotomy, of which three deaths occurred. Careful patient selection is extremely important in patients undergoing less invasive measure of sepsis control. The present study has demonstrated that patients with low colorectal anastomosis can be effectively treated with diverting stoma and drain insertion. Patients have a higher risk of definitive stoma in the case of anastomotic take down mainly due to surgical difficulty encountered during the redo anastomosis. ${ }^{33-35}$ Less invasive approaches in carefully selected patients will have a significant impact on morbidity and quality of life issues associated with a permanent stoma ${ }^{36}$.

\section{CONCLUSION}


This study found that initial presentation with MOF, upper GI origin of sepsis and ASA score $\geq 3$ are significant morbidity and mortality risk factors. Perioperative blood transfusion is also a mortality risk factor, while delayed extubation is a significant morbidity risk factor.

With aggressive management and control of the septic source of POP, morbidity and mortality rates can be decreased. 


\section{REFERENCES}

1. Martinez-Casas I, Sancho JJ, Nve E, et al. Preoperative risk factors for mortality after relaparotomy: analysis of 254 patients Langenbeck's archives of surgery / Deutsche Gesellschaft fur Chirurgie 2010: 395; 527-534

2. Kirshtein B, Roy-Shapira A, Domchik S, et al. Early relaparoscopy for management of suspected postoperative complications Journal of gastrointestinal surgery : official journal of the Society for Surgery of the Alimentary Tract 2008: 12; 1257-1262

3. Mulier S, Penninckx F, Verwaest C, et al. Factors affecting mortality in generalized postoperative peritonitis: multivariate analysis in 96 patients World journal of surgery 2003: $27 ; 379-384$

4. Riche FC, Dray X, Laisne MJ, et al. Factors associated with septic shock and mortality in generalized peritonitis: comparison between community-acquired and postoperative peritonitis Critical care 2009: 13; R99

5. Montravers P, Gauzit R, Muller C, et al. Emergence of antibiotic-resistant bacteria in cases of peritonitis after intraabdominal surgery affects the efficacy of empirical antimicrobial therapy Clinical infectious diseases : an official publication of the Infectious Diseases Society of America 1996: $23 ; 486-494$

6. Roehrborn A, Thomas L, Potreck O, et al. The microbiology of postoperative peritonitis Clinical infectious diseases : an official publication of the Infectious Diseases Society of America 2001: 33; $1513-1519$

7. Turrentine FE, Denlinger CE, Simpson VB, et al. Morbidity, mortality, cost, and survival estimates of gastrointestinal anastomotic leaks Journal of the American College of Surgeons 2015: 220; 195-206

8. Cozzaglio L, Giovenzana M, Biffi R, et al. Surgical management of duodenal stump fistula after elective gastrectomy for malignancy: an Italian retrospective multicenter study Gastric cancer : official journal of the International Gastric Cancer Association and the Japanese Gastric Cancer Association 2016: 19; 273-279

9. Montravers P, Dupont H, Gauzit R, et al. Candida as a risk factor for mortality in peritonitis Critical care medicine 2006: 34; 646-652

10. Koperna T, Schulz F Relaparotomy in peritonitis: prognosis and treatment of patients with persisting intraabdominal infection World journal of surgery 2000: 24; 32-37 
11. Linder MM, Wacha H, Feldmann U, et al. [The Mannheim peritonitis index. An instrument for the intraoperative prognosis of peritonitis] Der Chirurg; Zeitschrift fur alle Gebiete der operativen Medizen 1987: 58; 84-92

12. Dindo D, Demartines N, Clavien PA Classification of surgical complications: a new proposal with evaluation in a cohort of 6336 patients and results of a survey Annals of surgery 2004: $240 ; 205-213$

13. Parc Y, Frileux P, Vaillant JC, et al. Postoperative peritonitis originating from the duodenum: operative management by intubation and continuous intraluminal irrigation The British journal of surgery 1999: 86; 1207-1212

14. Canard G, Lefevre JH, Parc Y Management of duodenal perforation or fistula by intubation with the Levy drain. Surgical technique and postoperative management Journal of visceral surgery 2013: $150 ; 115-119$

15. Parc Y, Frileux P, Schmitt G, et al. Management of postoperative peritonitis after anterior resection: experience from a referral intensive care unit Diseases of the colon and rectum 2000: 43; 579-587; discussion 587-579

16. Dupont H, Bourichon A, Paugam-Burtz C, et al. Can yeast isolation in peritoneal fluid be predicted in intensive care unit patients with peritonitis? Critical care medicine 2003: 31; 752757

17. Calicis B, Parc Y, Caplin S, et al. Treatment of postoperative peritonitis of small-bowel origin with continuous enteral nutrition and succus entericus reinfusion Archives of surgery 2002: $137 ; 296-300$

18. Sakran N, Goitein D, Raziel A, et al. Gastric leaks after sleeve gastrectomy: a multicenter experience with 2,834 patients Surg Endosc 2013: 27; 240-245

19. Jacobsen HJ, Nergard BJ, Leifsson BG, et al. Management of suspected anastomotic leak after bariatric laparoscopic Roux-en-y gastric bypass The British journal of surgery 2014: 101; 417423

20. Knaus WA, Draper EA, Wagner DP, et al. APACHE II: a severity of disease classification system Critical care medicine 1985: 13; 818-829

21. Launey Y, Duteurtre B, Larmet R, et al. Risk factors for mortality in postoperative peritonitis in critically ill patients World J Crit Care Med 2017: 6; 48-55

22. Bennis $\mathrm{M}$, Parc $\mathrm{Y}$, Lefevre $\mathrm{JH}$, et al. Morbidity risk factors after low anterior resection with total mesorectal excision and coloanal anastomosis: a retrospective series of 483 patients Annals of surgery 2012: 255; 504-510 
23. Glance LG, Dick AW, Mukamel DB, et al. Association between intraoperative blood transfusion and mortality and morbidity in patients undergoing noncardiac surgery Anesthesiology 2011: $114 ; 283-292$

24. Bernard AC, Davenport DL, Chang PK, et al. Intraoperative transfusion of $1 \mathrm{U}$ to $2 \mathrm{U}$ packed red blood cells is associated with increased 30-day mortality, surgical-site infection, pneumonia, and sepsis in general surgery patients Journal of the American College of Surgeons 2009: 208; 931-937, 937 e931-932; discussion 938-939

25. Al-Refaie WB, Parsons HM, Markin A, et al. Blood transfusion and cancer surgery outcomes: a continued reason for concern Surgery 2012: 152; 344-354

26. Li L, Zhu D, Chen X, et al. Perioperative Allogenenic Blood Transfusion is Associated With Worse Clinical Outcome for Patients Undergoing Gastric Carcinoma Surgery: A Meta-Analysis Medicine (Baltimore) 2015: 94; e1574

27. Fragkou PC, Torrance HD, Pearse RM, et al. Perioperative blood transfusion is associated with a gene transcription profile characteristic of immunosuppression: a prospective cohort study Critical care 2014: 18; 541

28. Tartter PI Immunologic effects of blood transfusion Immunol Invest 1995: 24; 277-288

29. Wada H, Matsumoto T, Yamashita Y Diagnosis and treatment of disseminated intravascular coagulation (DIC) according to four DIC guidelines J Intensive Care 2014: 2; 15

30. Heredia-Rodriguez M, Pelaez MT, Fierro I, et al. Impact of ventilator-associated pneumonia on mortality and epidemiological features of patients with secondary peritonitis Ann Intensive Care 2016: 6; 34

31. Burtin C, Clerckx B, Robbeets C, et al. Early exercise in critically ill patients enhances shortterm functional recovery Critical care medicine 2009: 37; 2499-2505

32. Schweickert WD, Pohlman MC, Pohlman AS, et al. Early physical and occupational therapy in mechanically ventilated, critically ill patients: a randomised controlled trial Lancet 2009: 373; 1874-1882

33. Pitel S, Lefevre JH, Tiret E, et al. Redo coloanal anastomosis: a retrospective study of 66 patients Annals of surgery 2012: 256; 806-810; discussion 810-801

34. Lefevre JH, Bretagnol F, Maggiori L, et al. Redo surgery for failed colorectal or coloanal anastomosis: a valuable surgical challenge Surgery 2011: 149; 65-71

35. Maggiori L, Bretagnol F, Lefevre JH, et al. Conservative management is associated with a decreased risk of definitive stoma after anastomotic leakage complicating sphincter-saving resection for rectal cancer Colorectal Dis 2011: 13; 632-637 
36. Fucini C, Gattai R, Urena C, et al. Quality of life among five-year survivors after treatment for very low rectal cancer with or without a permanent abdominal stoma Annals of surgical oncology 2008: 15; 1099-1106 
Table 1. Characteristics of 191 patients at initial procedure before peritonitis

\begin{tabular}{ll}
\hline Characteristic & $\begin{array}{c}\text { Total }(\%) \\
\mathrm{n}=191\end{array}$ \\
\hline Age at operation* & $61(18-84)$ \\
Male & $97(50.8)$ \\
ASA Score $>3$ & $85(44.5)$ \\
BMI kg/m ${ }^{2 *}$ & $23(4-41)$ \\
Denutrition & $74(38.7)$ \\
Preoperative Chemotherapy & $18(9.4)$ \\
Preoperative Radiotherapy & $13(6.8)$ \\
Previous abdominal surgery & $92(48.2)$ \\
Peroperative Transfusion & $17(8.9)$ \\
\hline
\end{tabular}

*Mean \pm standard deviation (range)

$A S A$, American Society of Anesthesiologists; BMI: Body Mass Index; FAP: Familial Adenomatous Polyposis. 
Table 2. Indication for initial surgery

\begin{tabular}{lll}
\hline Characteristic & \multicolumn{2}{c}{$\begin{array}{c}\text { Total }(\%) \\
\mathrm{n}=191\end{array}$} \\
\hline Neoplasia & 94 & $(49.2)$ \\
Antrum & 8 & $(4.2)$ \\
Fundus & 8 & $(4.2)$ \\
Cardia & 7 & $(3.7)$ \\
Lower œsophagus & 4 & $(2.1)$ \\
Right colon & 17 & $(8.9)$ \\
Left colon \& upper rectum & 24 & $(12.7)$ \\
Rectum & 14 & $(7.3)$ \\
PAF & 4 & $(2.1)$ \\
Carcinosis & 4 & $(2.1)$ \\
Pelvic resurgence & 1 & $(0.5)$ \\
Gynecologic / Urologic neoplasia & 2 & $(1)$ \\
& & \\
Inflammatory bowel disease & 23 & $(12)$ \\
Emergency surgery & 41 & $(21.5)$ \\
Appendicectomy & 4 & $(2.1)$ \\
Small bowel obstruction & 8 & $(4.2)$ \\
Neoplasic obstruction & 10 & $(5.2)$ \\
Perforated diverticulitis & 3 & $(1.6)$ \\
Crohn disease & 6 & $(3.1)$ \\
Other & 10 & $(5.2)$ \\
\hline
\end{tabular}

FAP: Familial Adenomatous Polyposis. 
Table 3. Clinical presentation at relaparotomy.

Characteristic

Total $(\%)$

$\mathrm{n}=191$

Abdominal pain

$156(82)$

Tachycardia

$117(61)$

Peritoneal irritation sign

$105(55)$

Fever

93 (49)

Abnormal drainage

35 (18)

Post-operative ileus

$21(6)$

Evisceration

$12(6)$

MOF

$48 \quad(25.1)$

Septic shock

$65 \quad(16.5)$

Renal failure

45 (23.6)

Respiratory failure

41 (21.5)

Sepsis

176 (92)

APACHE II Score*

$10 \quad(1-39)$

White blood cell count

$$
\begin{aligned}
& >10000 \\
& 4000-10000
\end{aligned}
$$

$62 \quad(32.5)$

$<4000$

15 (7.9)

$213(14-652)$

CT scan sign

124 (64.9)

Pneumoperitoneum

$47 \quad(37.9)$

Intra-abdominal fluid

74 (59.7)

Abscess

52 (41.9)

Anastomotic leakage on opacification

$32(25.8)$

* Median \pm Standard deviation

$M O F$ : Multiple Organ Failure; CRP: C-Reactive Protein. 
Table 4. Perioperative findings during relaparotomy and surgical management.

\begin{tabular}{|c|c|}
\hline Characteristic & Total $(\%) \mathrm{n}=191$ \\
\hline Median Delay before reintervention * & $(1-195)$ \\
\hline Peroperative Transfusion & $85 \quad(44.5)$ \\
\hline Mannheim Score $\dagger$ & $26 \quad(4-43)$ \\
\hline Generalized Peritonitis & $88 \quad(46.1)$ \\
\hline $\begin{array}{l}\text { Peritonitis cause } \\
\text { Anastomotic leakage } \\
\text { Duodenal fistula } \\
\text { Perforation } \\
\text { Enteral necrosis } \\
\text { Colonic necrosis } \\
\text { Secondary leakage of stump left in the abdomen } \\
\text { Biliary fistula } \\
\text { No etiology found } \\
\text { Abscess }\end{array}$ & $\begin{array}{ll}127 & (66.5) \\
16 & (8.4) \\
40 & (20.9) \\
11 & (5.8) \\
12 & (6.3) \\
6 & (3.1) \\
2 & (1) \\
5 & (2.6) \\
10 & (5.2)\end{array}$ \\
\hline Evisceration & $14 \quad(7.3)$ \\
\hline $\begin{array}{l}\text { Surgical Management } \\
\text { Anastomosis take down } \\
\text { Intubation of the leakage } \\
\text { Duodenal intubation } \\
\text { Drainage of the leakage } \\
\text { Suture with derivation stoma } \\
\text { Redo anastomosis } \\
\text { Stoma on perforation } \\
\text { Enteral resection + stoma } \\
\text { Colonic resection }\end{array}$ & $\begin{array}{ll}99 & (51.8) \\
6 & (3.1) \\
14 & (7.3) \\
17 & (8.9) \\
22 & (11.5) \\
1 & (0.5) \\
16 & (8.4) \\
23 & (12) \\
10 & (5.2)\end{array}$ \\
\hline $\begin{array}{l}\text { Stoma } \\
\text { Jejunostomy } \\
\text { Feeding jejunostomy } \\
\text { Osophagostomy } \\
\text { Ileo-colostomy } \\
\text { Ileostomy } \\
\text { Colostomy } \\
\text { Hartmann's procedure } \\
1 \text { stoma } \\
2 \text { stoma } \\
3 \text { stoma }\end{array}$ & $\begin{array}{ll}156 & (81.7) \\
20 & (10.5) \\
34 & (17.8) \\
1 & (0.5) \\
31 & (16.2) \\
87 & (45.6) \\
51 & (26.7) \\
33 & (17.3) \\
122 & (63.9) \\
27 & (14.1) \\
5 & (2.6)\end{array}$ \\
\hline
\end{tabular}

* Days \pm standard deviation; $\uparrow$ Median \pm standard deviation 
Table 5. Postoperative course after relaparotomy for postoperative peritonitis

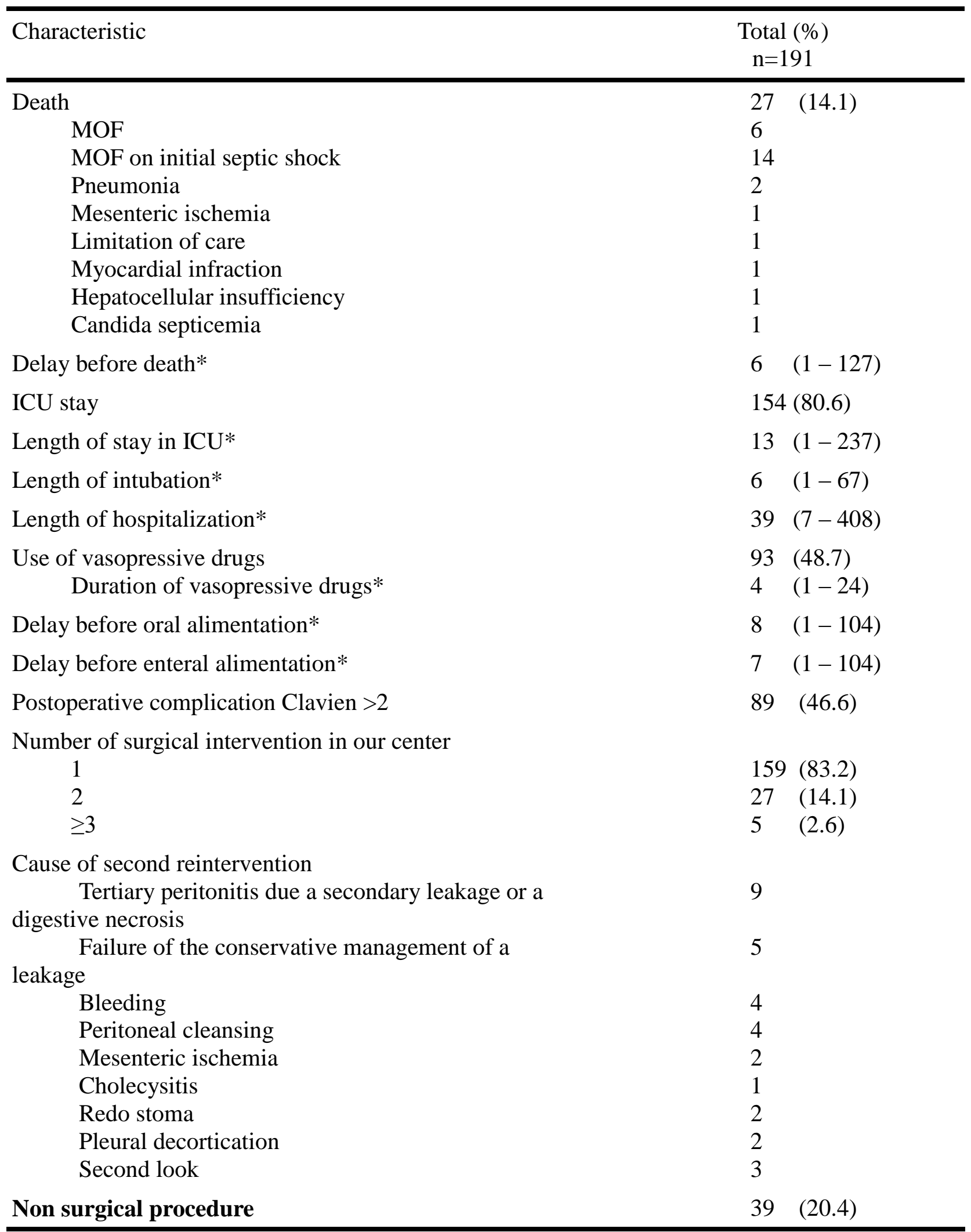

* Days \pm standard deviation.

MOF: Multi Organ Failure; ICU: Intensive Care Unit 
Table 6. Risk factors of mortality: univariate and multivariate analysis.

\begin{tabular}{|c|c|c|c|c|c|c|c|}
\hline \multirow[t]{2}{*}{ Variable } & \multirow[t]{2}{*}{$\mathrm{n}$} & \multirow{2}{*}{\multicolumn{2}{|c|}{$\begin{array}{c}\text { Death (\%) } \\
\mathrm{n}=27\end{array}$}} & \multirow{2}{*}{$\begin{array}{c}\begin{array}{c}\text { Univariate } \\
\text { analysis }\end{array} \\
\mathrm{p}\end{array}$} & \multicolumn{3}{|c|}{ Multivariate analysis } \\
\hline & & & & & OR & IC95\% & $\mathrm{p}$ \\
\hline Age & & & & 0.11 & & & 0.55 \\
\hline$>70$ years & 60 & 12 & (20) & & & & \\
\hline$<70$ years & 131 & 15 & (11.5) & & & & \\
\hline Sex & & & & 0.172 & & & 0.50 \\
\hline Male & 97 & 17 & $(17.5)$ & & & & \\
\hline Female & 94 & 10 & (10.6) & & & & \\
\hline ASA Score & & & & 0.0035 & 2.75 & $1.07-7.62$ & 0.037 \\
\hline$>2$ & 85 & 19 & $(22.4)$ & & & & \\
\hline$\leq 2$ & 106 & 8 & $(7.6)$ & & & & \\
\hline Malnutrition & & & & 0.131 & & & 0.47 \\
\hline Yes & 74 & 14 & $(7.3)$ & & & & \\
\hline No & 117 & 13 & (11.1) & & & & \\
\hline Neoplasia & & & & 0.097 & & & 0.52 \\
\hline Yes & 92 & 17 & (18.5) & & & & \\
\hline No & 99 & 10 & (10.1) & & & & \\
\hline POP origin & & & & 0.0017 & 3.55 & $1.32-9.56$ & 0.013 \\
\hline Upper GI & 36 & 11 & $(30.6)$ & & & & \\
\hline Lower GI & 155 & 16 & (10.3) & & & & \\
\hline Emergency initial surgery & & & & 0.54 & & & NI \\
\hline Yes & 41 & 7 & $(17.1)$ & & & & \\
\hline No & 150 & 20 & $(13.3)$ & & & & \\
\hline Transfer & & & & 0.39 & & & NI \\
\hline Yes & 63 & 11 & $(17.2)$ & & & & \\
\hline No & 128 & 16 & $(12.6)$ & & & & \\
\hline MOF & & & & $<0.001$ & 5.22 & $2.11-13.55$ & 0.004 \\
\hline Yes & 49 & 17 & $(34.7)$ & & & & \\
\hline No & 142 & 10 & (7) & & & & \\
\hline Shock & & & & $<0.001$ & & & 0.87 \\
\hline Yes & 65 & 18 & $(27.7)$ & & & & \\
\hline No & 126 & 9 & $(7.1)$ & & & & \\
\hline Renal failure & & & & $<0.001$ & & & 0.43 \\
\hline Yes & 45 & 14 & $(31.1)$ & & & & \\
\hline No & 146 & 13 & $(8.9)$ & & & & \\
\hline Respiratory failure & & & & $<0.001$ & & & 0.49 \\
\hline Yes & 46 & 15 & $(32.6)$ & & & & \\
\hline No & 145 & 12 & $(8.3)$ & & & & \\
\hline Peritonitis $>24 \mathrm{~h}$ & & & & 0.137 & & & 0.77 \\
\hline Yes & 101 & 18 & $(17.8)$ & & & & \\
\hline No & 90 & 9 & $(10)$ & & & & \\
\hline Generalized peritonitis & & & & 0.37 & & & NI \\
\hline Yes & 75 & 15 & $(20)$ & & & & \\
\hline No & 116 & 12 & $(10.3)$ & & & & \\
\hline Source septic & & & & 0.016 & & & 0.46 \\
\hline$>1$ & 38 & 10 & $(26.3)$ & & & & \\
\hline$=1$ & 153 & 17 & $(11.1)$ & & & & \\
\hline \multicolumn{8}{|c|}{ Transfusion during relaparotomy } \\
\hline Yes & & & & 0.004 & 2.70 & $1.05-7.47$ & 0.04 \\
\hline \multirow[t]{2}{*}{ No } & 85 & 19 & $(22.4)$ & & & & \\
\hline & 106 & 8 & $(7.6)$ & & & & \\
\hline Mannheim Score & & & & $<0.001$ & & & NI \\
\hline$\geq 30$ & 60 & 19 & $(31.2)$ & & & & \\
\hline$<30$ & 130 & 8 & $(6.2)$ & & & & \\
\hline APACHE II Score & & & & $<0.001$ & & & NI \\
\hline$\geq 15$ & 54 & 17 & $(31.5)$ & & & & \\
\hline$<15$ & 117 & 6 & $(5.1)$ & & & & \\
\hline Delay since first procedure & & & $(2-56)$ & 0.13 & & & NI \\
\hline
\end{tabular}


Immediate postoperative

extubation

Yes

No
0.006

0.95

$\begin{array}{lll}82 & 5 & (6.1)\end{array}$

$109 \quad 22 \quad(20.2)$

ASA: American Society of Anesthesiologists; POP: Post Operative Peritonitis; GI: gastro Intestinal; MOF: Multi Organ Failure; NI: Non Include in the multivariate analysis 
Table 7. Risk factors of severe morbidity: univariate and multivariate analysis

\begin{tabular}{|c|c|c|c|c|c|c|c|}
\hline \multirow[t]{2}{*}{ Variable } & \multirow[t]{2}{*}{$\mathrm{n}$} & \multicolumn{2}{|c|}{$\begin{array}{c}\text { Clavien }>2(\%) \\
\mathrm{n}=88\end{array}$} & \multirow{2}{*}{$\begin{array}{c}\begin{array}{c}\text { Univariate } \\
\text { analysis }\end{array} \\
\mathrm{p}\end{array}$} & \multicolumn{3}{|c|}{ Multivariate analysis } \\
\hline & & & & & OR & IC95\% & $\mathrm{p}$ \\
\hline Age & & & & 0.97 & & & NI \\
\hline$>70$ yo & 60 & 28 & $(33.3)$ & & & & \\
\hline$<70$ yo & 131 & 60 & $(45.8)$ & & & & \\
\hline Sex & & & & 0.024 & & & 0.11 \\
\hline Male & 97 & 53 & $(54.6)$ & & & & \\
\hline Female & 94 & 35 & $(37.2)$ & & & & \\
\hline ASA Score & & & & 0.002 & & & 0.069 \\
\hline$>2$ & 85 & 50 & $(58.8)$ & & & & \\
\hline$\leq 2$ & 106 & 38 & $(35.8)$ & & & & \\
\hline Malnutrition & & & & 0.179 & & & 0.73 \\
\hline Yes & 74 & 39 & $(52.7)$ & & & & \\
\hline No & 117 & 49 & $(41.9)$ & & & & \\
\hline Neoplasia & & & & 0.026 & & & NI \\
\hline Yes & 92 & 39 & $(42.4)$ & & & & \\
\hline No & 99 & 50 & $(50.4)$ & & & & \\
\hline POP origin & & & & 0.001 & 3.74 & $1.59-9.44$ & 0.003 \\
\hline Upper GI & 36 & 27 & (75) & & & & \\
\hline Lower GI & 155 & 62 & $(40)$ & & & & \\
\hline Transfer & & & & 0.19 & & & 0.98 \\
\hline Yes & 63 & 34 & (54) & & & & \\
\hline No & 128 & 54 & $(42.2)$ & & & & \\
\hline MOF & & & & $<0.001$ & 2.74 & $1.26-6.19$ & 0.013 \\
\hline Yes & 49 & 36 & $(73.5)$ & & & & \\
\hline No & 142 & 52 & (36.6) & & & & \\
\hline Shock & & & & $<0.001$ & & & 0.42 \\
\hline Yes & 65 & 45 & $(69.2)$ & & & & \\
\hline No & 126 & 43 & $(34.1)$ & & & & \\
\hline Peritonitis > 24h & & & & 0.46 & & & NI \\
\hline Yes & 101 & 49 & $(48.5)$ & & & & \\
\hline No & 90 & 39 & $(43.3)$ & & & & \\
\hline $\begin{array}{l}\text { Transfusion during } \\
\text { relaparotomy }\end{array}$ & & & & 0.014 & & & 0.98 \\
\hline Yes & 85 & 48 & $(56.5)$ & & & & \\
\hline No & 106 & 40 & $(37.7)$ & & & & \\
\hline Mannheim Score & & & & 0.024 & & & NI \\
\hline$\geq 30$ & 60 & 36 & $(60)$ & & & & \\
\hline$<30$ & 130 & 52 & $(40)$ & & & & \\
\hline APACHE II Score & & & & $<0.001$ & & & NI \\
\hline$\geq 15$ & 54 & 39 & $(72.2)$ & & & & \\
\hline$<15$ & 117 & 43 & $(36.8)$ & & & & \\
\hline Immediate postoperative & & & & $<0.001$ & 0.27 & $0.14-0.55$ & 0.003 \\
\hline extubation & 82 & 20 & $(24.4)$ & & & & \\
\hline Yes & 109 & 68 & $(62.4)$ & & & & \\
\hline No & & & & & & & \\
\hline $\begin{array}{l}\text { Delay before enteral } \\
\text { alimentation* }\end{array}$ & $6(1-24)$ & & $-104)$ & $<0.001$ & & & NI \\
\hline
\end{tabular}

*Days \pm Standard deviation

$M O F$ : Multi Organ Failure; NI: Non Included in the multivariate analysis. 